\title{
The Effect of Garlic (Allium Sativum L) flour as a Feed Additive on Performance and Carcass Characteristics of Super Free-Range Chickens
}

\author{
Jein Rinny Leke ${ }^{\mathrm{a},{ }^{*}}$, Erwin Wantasen ${ }^{\mathrm{a}}$, Florencia Sompie ${ }^{\mathrm{a}}$, Ratna Siahaan ${ }^{\mathrm{b}}$, James Hellyward ${ }^{\mathrm{c}}$, \\ Mirzah Mirzah $^{\mathrm{c}}$ \\ ${ }^{a}$ Animal Husbandry Faculty, Sam Ratulangi University, Manado, 95115, Indonesia \\ ${ }^{b}$ Biology Department, Faculty of Mathematics and Natural Science, Sam Ratulangi University, Manado, 95115, Indonesia \\ ${ }^{c}$ Animal Husbandry Faculty, Andalas, Padang, 25163, Indonesia \\ Corresponding author: "rinileke@yahoo.com
}

\begin{abstract}
The objective of this study was to determine the effects of feeding Garlic Flour (GF) meals on the performances and carcass characteristics of super free-range chickens (SFRCs). Two hundred SFRCs were divided into 5 treatments with 5 replicates per replicate containing eight chickens. This experiment used a completely randomized design (CRD) with Basal Feed (BF) and GF. The 5 treatments were $\mathrm{P0}=\mathrm{BF}+0 \% \mathrm{GF}, \mathrm{P} 1=\mathrm{BF}+1 \% \mathrm{GF}, \mathrm{P} 2=\mathrm{BF}+\mathbf{2} \% \mathrm{GF}, \mathrm{P3}=\mathrm{BF}+3 \% \mathrm{GF}$, and $\mathrm{P} 4=\mathrm{BF}+4 \% \mathrm{GF}$. Variables were the weight of dressed, carcass, breast, heart, liver; abdominal fat, cholesterol, HDL, LDL of blood; cholesterol, water content, protein content, and fat content. Data were analyzed using the ANOVA test, and significant differences between treatments were determined using a Duncan multiple-range test (DMRT). The result of this study showed that $\mathrm{P} 4$ was significantly different $(\mathrm{P}<0.01)$ between percentages of dressed weight, percentages of the carcass, breast weight, heart weight, liver weight, abdominal fat, blood cholesterol, blood HDL, blood LDL, cholesterol, water content, protein, and fat of meat. In conclusion, GF can act as an organic food additive which $P 4$ could increase growth and carcass performances with no negative effects on SFRCs. This research recommends that garlic be used for chicken feed; it can also be a juice drink.
\end{abstract}

Keywords—Feed additive; garlic flour; super free-range chicken; native chicken.

\section{INTRODUCTION}

Native chickens are raised mainly by people living in rural areas. The protein sources obtained from native chicken include meat and eggs. However, the availability of native chickens is still minimal, and the production of the chickens is limited; thus, native chickens do not meet the demand [1][3]. Super free-range chickens (SFRCs) are beneficial because they can produce in large quantities with uniform weights and a faster growth rate than ordinary native chickens or local chickens. The chickens also have a low mortality rate, high adaptability to various environments, and a savory taste. The SFRC also grows extremely fast.

In the condition of the Covid-19 pandemic, people are searching for food protein sources that are safe for consumption. However, the needs of SFRC by consumers are still limited because SFRC productivity is still low to meet the food security standards. In that context, a concerted effort should be put towards preparing high-quality SFRC products, meat that is safe for consumption. Chicken meat is the skeletal muscle of a chicken carcass that is safe, proper, and commonly consumed by humans. Chicken meat comprises balanced nutrition, which is needed by the body. Meat quality is a combination and several meat characteristics that ensure the safety of the consumption of meat products. The meat quality can be reflected from nutrition, physical and sensory properties. The nutritional properties of meat are indicated by the water content, protein, and fat [4]. Feed additives are commonly used in poultry farms to spur growth and increase poultry feed efficiency with components such as antibiotics, hormones, etc. However, poultry farmers tend to abandon feed additives because they are unsafe and harmful to consumers. The use of antibiotics in livestock can also cause antibiotic resistance, which negatively impacts livestock [5]. Indonesia prohibited antibiotic growth promoters (AGPs), 
thus searching for sources to substitute antibiotics with natural ingredients.

Plant ingredients as feed additives can replace the prohibition on the use of antibiotics [6]. Garlic is one of the natural ingredients used as an antibiotic in chickens to produce healthy, whole, and halal chicken meat for humans. In Indonesia, garlic is used traditionally as food and for medicinal purposes. Previous research has proven garlic as an AGPs for growth booster and livestock health to chicken broiler [7]. Garlic (Allium sativum L) is a herbal plant; besides its use as a food flavoring, garlic has another function as an antibacterial (antibiotic) containing allicin and alliin to prevent diseases. Garlic has 33 sulfur components, 17 amino acids, and some minerals and enzymes that make the smell characteristic of garlic medicines [8], where sulfur is one of the compounds most responsible for garlic taste aroma and pharmacological properties [9]. This plant also contains saponin and flavonoids that support anti-blood thrombotic, blood lipid, neuron pressure, antibacterial, and inhibitor of food pathogen. These components can decrease cholesterol. Garlic contains active ingredients that are classified into essential oils, namely allium and scordinin [10].

Previous studies reported that garlic extract in layer chicken feed as much as $0.0032 \%$ can increase the aroma and test of chicken eggs and increase the yolk color. These results indicate that garlic extract can produce egg production in the feed, and the resulting eggs can be consumed in the raw form[9]. Studies have also reported that flavonoid in tomatoes flour ratio up to $8 \%$ in the diet can reduce cholesterol in laying hens[11], and diallyl disulfide in garlic can inhibit the formations of cholesterol and fatty acid which cause heart disease and protect the body from cancer. Studies have shown that giving raw garlic in laying duck feed results in low cholesterol duck eggs [10]. Dialyl trisulfide can prevent infection and inflammation on the lining of the brain or bone marrow. Garlic is also a phytochemical component that inhibits microorganism growth in the digestive tract. Toxicity from phytochemical garlic act as a prebiotic pathogenic in the digestive tract, increasing feed consumption[12], [13]. The prebiotic mechanism of garlic can boost livestock immunity, lactate acid bacteria (BAL); therefore, the prebiotic mechanism can positively contribute to pathogen bacteria. Previous studies reported that chicken broiler feed with probiotic lactobacillus acidophilus in rations could increase body weight, decrease FCR, and mortality[14]. Garlic can also increase pancreas enzyme activity that can fix nutrition absorption.

Garlic flour has been used as an additive in previous studies. Garlic flour gives an advantage to humans and livestock. For example, garlic flour acts as an antimicrobial, antioxidant, anticancer, immune-modulatory, hypoglycemic, anti-inflammatory, and anti-hypertensive [15]. This research showed that laying hens with $8 \%$ garlic flour treatments increased egg productivity and quality. The performances of egg qualities increased due to garlic juice treatments about $0.25 \%, 0.5 \%$, and $1 \%[16]$.

Furthermore, garlic juice had suppressed E. colli bacteria growth and decreasing egg cholesterol. Garlic flour in chicken feed laying eggs up to $4 \%$ can increase egg weight. The albumen weight increases until the addition of $8 \%$ garlic flour. This research recommends that adding garlic flour in the feed up to $8 \%$ can be done without negatively affecting egg quality[17]. Feeding garlic as a prebiotic on broiler chicken's performance showed that feeding garlic flour for $1,5 \%$ can increase body weight, FCR, and give 1\% garlic flour [15]. Garlic flour, at 1,5\%, affected hemoglobin, total RBC, cholesterol, triglycerides, HDL, and LDL [18]. Garlic flour also increased crude protein of meat percentage[19]. Supplementation of $2 \%$ garlic in the rations can improve the quality of 42 day ages broiler chicken meat. Therefore, the current research objective aims to determine the effect of GF treatments as feed additives to increase the performances and characteristics of SFRCs.

\section{MAterial AND Method}

\section{A. Material}

This research used 200 super-free-range chickens (SFRC). The nutrient content was presented in Table 1. The composition of nutrient content was adjusted to the SFRC needs. Garlic was bought from the local market, and it was sliced and cut into small pieces without removing the skin, then sun-dried for 4 to 5 days. Dried garlic was milled until it became powder/flour at the Animal Husbandry Company. The garlic flour was chemically analyzed to determine nitrogen, ether extract, crude fiber, and ash using a standard method. Samples of each feed material used are in Table 1. Dry matter (DM), crude protein (CP), crude fiber (CF), ether extract (EE), and total ash content using the AOAC method (1990). Nitrogen was determined using the Kjeldahl method, and $\mathrm{CP}$ was calculated by multiplying $\mathrm{N}$ content by 6.25 .

\section{B. Method}

Figure 1 illustrated the research methodology and consisted of three main stages: material collection, animal experiments, and laboratory analysis. The collection process was carried out to mix the nutrient composition of SFRC. Ingredients used were garlic, corn, fine bran, concentrate, soybean meal, and vitamins. Experiments on chickens were carried out using the level-based treatment for 16 weeks. Laboratory analysis was carried out to get proximate chicken meat of SFRC samples and chicken blood samples and then testing data analysis. 


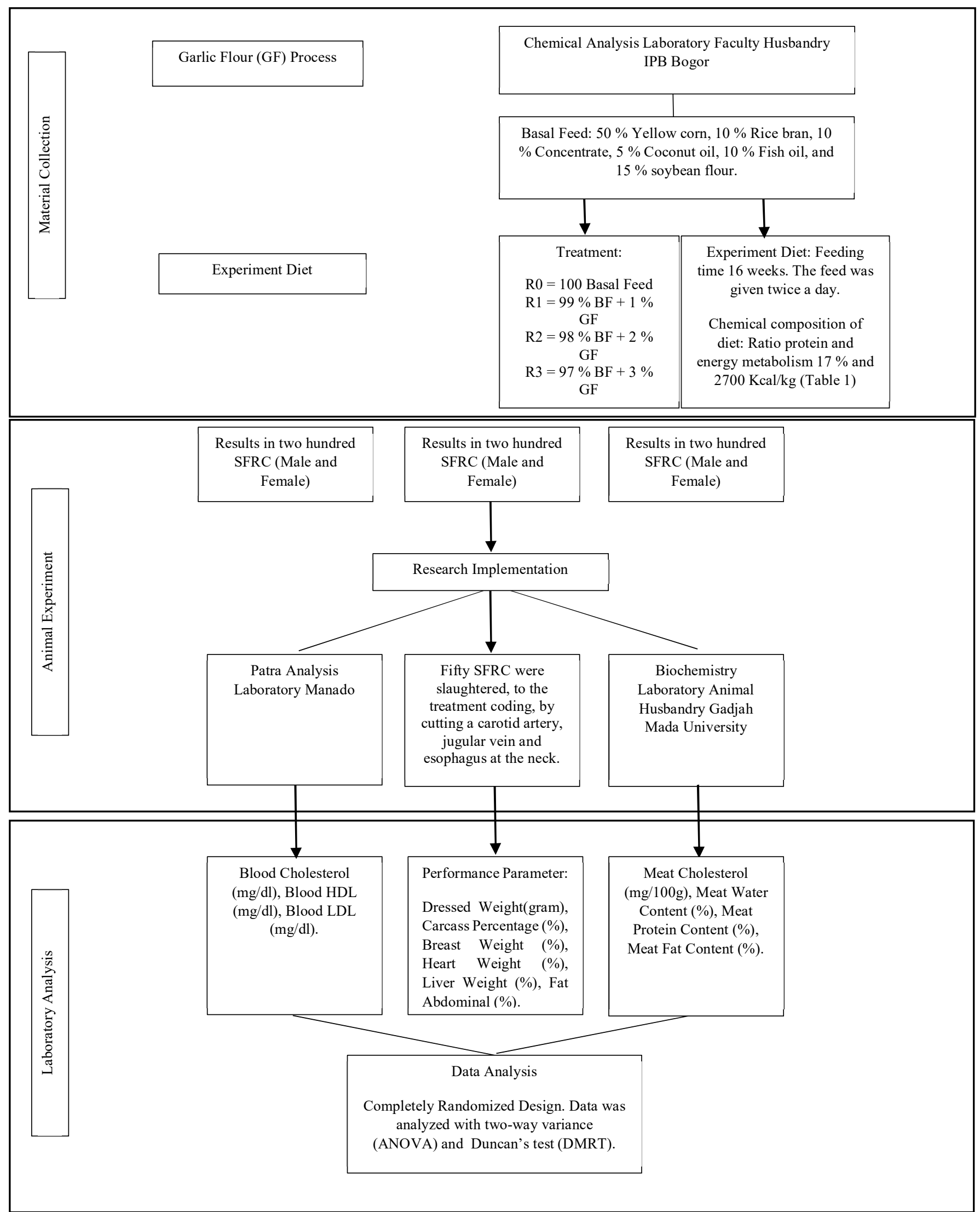

Fig. 1 Methodology Flowchart

In vivo method was used with a Completely Randomized Design (CRD) with five treatments (R0, R1, R2, R3, and R4) and five replicates (U1, U2, U3, U4, and U5). Each treatment unit contained 25 SFRCs, with each replicate containing eight SFRC. The total was 200 SFRCs. 
TABLE I

CHEMICAL COMPOSITION OF DIET

\begin{tabular}{lccccc}
\hline \multicolumn{1}{c}{ Nutrients } & \multicolumn{5}{c}{ Diets } \\
& R0 & R1 & R2 & R3 & R4 \\
\hline Crude Protein & 17.62 & 17.66 & 17.71 & 17.77 & 17.82 \\
(\%) & & & & & \\
Crude Fat (\%) & 5.99 & 5.96 & 5.94 & 5.91 & 5.89 \\
Calcium (\%) & 4.77 & 4.76 & 4.76 & 4.76 & 4.70 \\
Phosphor (\%) & 2.36 & 2.33 & 2.31 & 2.22 & 2.19 \\
ME (Kcal/kg) & 2751.55 & 2721.33 & 2721.16 & 2701.01 & 2720.83 \\
\hline
\end{tabular}

Note:

$\mathrm{GF}=$ Garlic flour

Analyzed by Integrated Laboratory- Department of Nutrition and Feed

Technology- Faculty of Animal Science- IPB University, Bogor.

Level of GF in Basal Feed:

R0 $=$ Basal Feed $(\mathrm{BF})-$ Non-GF

$\mathrm{R} 1=99 \% \mathrm{BF}+1 \% \mathrm{GF} ; \mathrm{R} 2=98 \% \mathrm{BF}+2 \% \mathrm{GF}$

$\mathrm{R} 3=97 \% \mathrm{BF}+3 \% \mathrm{GF} ; \mathrm{R} 4=96 \% \mathrm{BF}+4 \% \mathrm{GF}$

Data was analyzed with two-way variance (ANOVA) and continued with the Duncan multiple range test (DMRT). Values were expressed as the mean (standard error) of the mean $($ SEM) at the level of significance $(p<0.05)$. The implementation of the study consisted of two stages, as follows:

1) Maintenance stage without treatments: The maintenance stage was used for adaptation periods of SFRCs for 21 days in the SFRC heater. The SFRC came at 6 p.m. and was immediately given a brown sugar water drink to reduce stress on the first day. From the second day to the last day, SFRC were fed Bravo 1(511B) flour, convenient with a value of SFRC needs.

2) Maintenance stage with treatments: In this step, SFRCs were fed with GF treatments. The first ratio started in the fourth week when SFRCs were 28-days old (on eighthday maintenance) for 16 weeks (the fourth week to the twentieth week). The mixture of non-GF feed consisted of $50 \%$ yellow corn, $10 \%$ rice bran, $10 \%$ concentrate, $5 \%$ coconut oil, $10 \%$ fish flour, and $15 \%$ soybean flour. 125 gram/heads. The feed was given twice a day, i.e., the first meal $70 \%$ in the morning and $30 \%$ in the afternoon. The water was given ad libitum. Before SFRCs were slaughtered, they were fasted for 12 hours to empty their digestive tract from foods and weighed to determine the weight. A total of two SFRCs were chosen randomly from each box to represent each replication. Fifty SFRCs were slaughtered, according to the treatments coding, by cutting a carotid artery, jugular vein, and esophagus at the neck. During slaughter, large quantities of blood came out, weighed about $4 \%$ of body weight. After the slaughtering process, the feathers were plucked and cleaned by dipping the chickens into hot water at temperatures $50-54^{\circ} \mathrm{C}$ for 30 seconds. The following process was removing the head and internal organs by separation of cache, trachea, and the oil glands. The body cavity was opened by making an incision from the cloaca towards the breastbone. The cloaca and internal organs were removed.

3) Performance Parameter: Dressed weight, carcass percentage, abdominal fat, liver percentage, and heart percentage. The weighing was done at each stage, and the carcass was cooled and then also weighed. The carcass was cut into several pieces, namely wings, chest, upper and lower thighs. All the pieces were weighed according to the Soeparno method [20]. Then, the skin, meat, and bone were separated and weighed. The percentage of the carcass was determined by weighing the carcass weight removed from the head, leg, viscera, blood, and neck hair and divided by the carcass weight. Measurement of breast weight was determined by weighing the breast chicken and divided by the slaughter weight.

$$
\begin{gathered}
\text { Carcass weight }=\text { Weight of life }-(\text { hair, head, feet, viscera, blood and neck }) \\
\text { Percentage of carcass }=\frac{\text { Weight of carcass }}{\text { Weight of life }} \times 100 \% \\
\text { Percentage of abdominal fat } \\
=\frac{\text { Weight of fat abdominal }}{\text { Weight of life }} \times 100 \%
\end{gathered}
$$

The Kosher method was used in the cutting process. The cutting process was done by cutting the carotid artery, jugular vein, and esophagus. Blood was collected and dipped in hot water to facilitate the removal of chicken feathers. The following step was to remove visceral organs, liver, gizzard, and intestines, separated and weighed to calculate the percentage.

4) Performance's parameters: SRFC chicken blood sampling: The blood sampling method was done randomly for each flock unit. The blood samples were collected at 6 a.m. from chickens aged 18 weeks. Blood was collected through the brachial vein and put into a vacuum tube EDTA K-2 using Gudev et al. method [21]. The blood sample was put into a box waiting to be analyzed. Performance procedure was carried out in the following stages. Blood was centrifuged to separate blood plasma and then put into a "cup sample" and stored in a freezer with a minimum temperature of $2^{\circ} \mathrm{C}$. The method used for cholesterol analysis was the enzymatic colorimetric test (CHOD-POD) method with "reagen kit" cypress diagnostics production. Determination of LDL levels using a friedwald formula with reduction triglyceride levels and HDL levels.

5) Characteristics Parameters: Sampling of SFRC chicken was done by preparing $50 \mathrm{~g}$ of breast meat and proximate analysis to determine the chemical composition of meat. SFRC chicken meat samples were taken from the GF treatment, including $1 \%, 2 \%, 3 \%$, and $4 \%$. The chemical quality of the meat was moisture, ash, protein, and fat content. The chemical content of the meat was proximately analyzed by SNI 01-2891-1992 (Indonesian National Standardization Agency for Indonesia. The skinless milled meat sample was extracted and analyzed for cholesterol and total fat. Meat cholesterol, carcass fat levels, and water content were analyzed by using AOAC method [22]. The analysis was conducted to determine the effect of GF flour on the performance and characteristics of SFRCs.

6) Parameter: The parameters were Dressed weight (gram), carcass percentage (\%), breast weight( $\%)$, heart weight $(\%)$, liver weight $(\%)$, fat abdominal (\%), blood cholesterol(mg/dl), blood HDL(mg/dl), blood LDL (mg/dl), meat cholesterol $(\mathrm{mg} / 100 \mathrm{~g})$, meat water content $(\%)$, meat protein content $(\%)$, meat fat content $(\%)$. Furthermore, obtained data was analyzed by ANOVA and Duncan's test [23]. 


\section{RESULT AND DISCUSSION}

\section{A. Dressed Weight}

Dressed weight in each SFRC was increased after GF treatments. The result showed that the additions of GF on level $4 \%$ increased the dressed weight. Dressed weight in this experiment was 1217-1275 grams. The garlic treatment of 4\% resulted in a higher dressed weight than 1188.251355.13gram from SNC study [20].

The variance results in Table 2 showed that the dressed weight of SFRC was significantly different $(\mathrm{P}<0.01)$. Further test with Duncan's range test showed that R0 was significantly different $(\mathrm{P}<0.01)$ from $\mathrm{R} 1, \mathrm{R} 2, \mathrm{R} 3$, and $\mathrm{R} 4$, but between R1, R2, R3 were not significantly different $(\mathrm{P}>0.05)$, whereas R4 was different significantly $(\mathrm{P}<0.01)$ with R0, R1, $\mathrm{R} 2$, and R3.

The increasing dressed weight by treatment garlic $4 \%$ is attributed to the presence of phytochemical components that inhibit the growth of microorganisms and prebiotic pathogenic in the digestive tract. Garlic flour in chicken feed has a positive contribution to pathogenic bacteria, thus increasing Lactic Acid Bacteria (LAB) [14].

Microvilli have responsible for feed absorption substances in the small intestine. Thus, the digestibility of food substances in SFRC is improved. Besides that, the absorption of food substances becomes more efficient, resulting in the high retention of food substances, especially proteins that influence body weight. Phenolic active compounds can protect intestinal villi and are responsible for absorbing food substances in the chicken intestine. Garlic contains 33 active compounds containing sulfur, several enzymes, 17 amino acids, and minerals, including selenium. Furthermore, Albumen weight increased until garlic powder supplementation of up to $8 \%$. Therefore, using $8 \%$ garlic powder supplementation on laying hen ration is recommended, and it has no negative effects on egg quality characteristics [17].

\section{B. Percentages of Carcass}

The carcass percentage of SFRC fed with GF treatments up to $12 \%$ showed $73.63-75.11 \%$. These results were higher than the previously reported carcass percentage of 59.95-64.15\% [25]. Carcass percentage of broiler chickens fed with normal feed Folate (NF) was $65.07 \%$ and without folate (FD) was $64.73 \%$ [26]. The study's findings showed that the percentage of the SFRC carcass was higher than the percentage of Merawang chicken carcass 57.93\% [27].

The percentage of SFRC weight was significantly different $(\mathrm{P}<0.01)$. The treatment $\mathrm{R} 0$ was significantly different $(\mathrm{P}<$ 0.01 ) with R1, R2, R3, and R4, but between R1, R2, and R3 were not significantly different $(\mathrm{P}>0.05)$ and was significantly different $(\mathrm{P}<0.01)$ with $\mathrm{R} 4$. This revealed that the addition of GF up to $4 \%$ could increase the percentage of carcasses. The percentage of SFRC carcasses was obtained from carcass data without feathers, head, neck, legs, and internal contents. The decisive carcass in SFRC production carcass production is related to body weight. SFRC varies according to body size, level of obesity and level of chest weight.

GF contains allicin, an amino acid that is essential for the formation and development of cells. Allicin contains gurwich rays (sinargurwich) that have the function of mitogenic radiation, which can accelerate and multiply the formation of cells in the body that influent and reached optimal chicken weight [28], [29].

TABLE II

EfFect of Adding GFM to Percentages of Dressed Weight, CARCASs, Breast Weight, Heart (\%), Liver, and Abdominal Fat on SFRC

\begin{tabular}{|c|c|c|c|c|c|}
\hline Var & R0 & R1 & $\mathrm{R} 2$ & R3 & $\mathrm{R} 4$ \\
\hline Dressed wei & $1217^{\mathrm{a}} \pm 11.44$ & $1260^{\mathrm{b}} \pm 9.28$ & $1264^{b}+20.27$ & $1259^{\mathrm{b}} \pm 18.10$ & $1275^{\mathrm{c}} \pm 17.92$ \\
\hline Per & $73.63^{\mathrm{a}} \pm 0.00$ & $74.01^{\mathrm{b}} \pm 0.01$ & $74.13^{\mathrm{b}} \pm 0.00$ & $74.85^{b} \pm 0.01$ & $75.11^{\mathrm{c}} \pm 0.01$ \\
\hline Breast weight (\%) & $20.52^{\mathrm{a}} \pm 1.22$ & $20.93^{\mathrm{a}} \pm 1.24$ & $21.411^{b}+1.61$ & $21.75^{\mathrm{b}} \pm 1.50$ & $21.67^{b} \pm 0.80$ \\
\hline Heart weight percentage $(\%$ & $0.64^{\mathrm{b}} \pm 0.01$ & $0.63^{\mathrm{a}} \pm 0.00$ & $0.63^{a}+0.07$ & $0.66^{\mathrm{c}} \pm 0.08$ & $0.67^{c} \pm 0.04$ \\
\hline Liver weight percentage (\%) & $2.76^{\mathrm{a}} \pm 0.01$ & $2.74^{\mathrm{a}} \pm 0.00$ & $2.80^{b} \pm 0.06$ & $2.86^{b}+0.07$ & $2.88^{\mathrm{b}} \pm 0.04$ \\
\hline Fat abdomen $(\%)$ & $1.33^{\mathrm{b}} \pm 0.17$ & $1.49^{\mathrm{c}} \pm 0.04$ & $1.29^{\mathrm{a}} \pm 0.24$ & $1.44^{\mathrm{c}} \pm 0.06$ & $1.24^{\mathrm{a}}+0.11$ \\
\hline
\end{tabular}

Note: $\left.{ }^{*}\right)$ different superscripts in the same column show significant differences $(\mathrm{P}<0.01)$

\section{Percentages of Breast Weight}

The percentage of the breast weight of SFRC fed with GF up to $4 \%$ were $20.52 \%-21.67 \%$. The GF at $4 \%$ had a significant effect on breast weight $(\mathrm{P}<0.01)$, and Duncan test showed that $\mathrm{R} 0$ and $\mathrm{R} 1$ were significantly different $(\mathrm{P}<0.01)$ from R2, R3, and R4, but between R2, R3, and R4 were not significantly different $(\mathrm{P}>0.01)$. These results imply that a higher level of GF can increase the percentage of SFRC breast weight. This indicates that SFRC breast meat is lower than the broiler breast meat study. The results of the percentage of breast weight showed were $27.05-26.32 \%$ of the treatment effect of folate deficiency at the age of 21 - 42 days [26].

\section{Percentages of Heart Weight}

The SFRC percentage of heart weight with the treatment of GF $4 \%$ resulted in $0.63 \%-0.67 \%$. Poultry generally has different heart sizes. The average heart weight, which resulted after treatment of GF was $0.5 \%-1.42 \%$ of the live weight[30]. The average heart weight of each treatment was in a normal range of heart chicken. The variety of GF analysis results up to $4 \%$ in SFRC had a significant effect $(\mathrm{P}<0.01)$. The percentage of heart weight R0 was significantly different $(\mathrm{P}<0.01)$ from R1, R2, R3, and R4, but between R1 and R2, $\mathrm{R} 3$ and $\mathrm{R} 4$ were not significantly different $(\mathrm{P}<0.01)$. A large percentage of the heart depends on sex, age, body weight, and animal activity. This shows that GF can affect the metabolic activities of internal organs[30]. The process of metabolism 
occurs after the feed enters the body of poultry. This metabolism process will affect gizzard, liver, and heart work activities

\section{E. Percentages of Liver Weight}

The liver is the largest organ in the body. The liver has several functions, including exchanging substances from protein, fat, bile, secretion, detoxifying toxic compounds, and excusing metabolite compounds that are no longer useful. The percentages of the weight SNC liver given the GF up to $12 \%$ were $2.74 \%-2.88 \%$. The treatments up to $4 \%$ GF in SFRC showed a significant effect on liver weight percentages $(\mathrm{P}<0.01)$. The percentages of liver weights $\mathrm{R} 0$ and $\mathrm{R} 1$ differed significantly $(\mathrm{P}<0.01)$ with $\mathrm{R} 2, \mathrm{R} 3$, and $\mathrm{R} 4$, whereas between $\mathrm{R} 0$ and R1 were not significantly different $(\mathrm{P}>0.05)$ and between R2, R3, and R4 were not significantly different $(\mathrm{P}>0.05)$.

These results showed that the percentage of liver weight was increased because of the high levels of allicin in garlic, where the compounds include unsaturated oxidant disulfide. The biochemical mechanism is as follows: the side chain of unsaturated allyl is easily reduced to a saturated propyl chain, thereby increasing levels of NADPH in the body, even though NDPH is needed in cholesterol biosynthesis. In addition, allicin is also considered capable of binding to the-SH group, which is part of the functional coenzyme-A in the sulfhydryl group that is needed for cholesterol biosynthesis. The liver is one of the digestive glands that secretes bile and is collected in the gallbladder. Bile is used to emulsify fat [31].

Fat liver content 3-5\% of wet liver weight or 10-15\% liver dry weight. The normal liver can store $60-70 \%$ fat from the dry weight of the liver. The liver is also a fat-storage area. High accumulation of belly fat is caused by high levels of triglycerides in fat tissue.

\section{F. Percentages of Abdomen Fat}

The average percentage of abdominal fat SRFC fed with GF was $1.24-1.49 \%$. The variance analysis showed that GF level up to $4 \%$ had a significant effect $(\mathrm{P}>0.01)$. Duncan's test results showed that $\mathrm{R} 0$ was significantly different $(\mathrm{P}<0.01)$ from R1, R2, R3, and R4, but between R1, R2, and R2, R4 were not significantly different $(\mathrm{P}>0.05)$. The results of the percentage of abdominal fat from broilers from the effect of folate deficiency at the age of $21-42$ days was $2.04-2.74 \%$ followed by a further test that the percentage of abdominal fat was not significantly different [32].

This showed that the addition of GF to $4 \%$ could reduce the percentage of abdominal fat. Garlic contains sulfur which can shed fat. The distribution of fat in the chicken body was decreased with the addition of GF in SRFC ratio. This shows that GF containing high allicin that inhibits enzymes involved in fat synthesis can affect fat metabolism. The component of allicin in garlic can inhibit the synthesis of fatty acids in the liver, reducing levels of meat fat. Meat fat is negatively correlated with meat protein. This shows that fat is decreasing, followed by increasing protein in meat and vice versa. In addition, fat is also positively correlated with cholesterol because cholesterol is part of fat [33]. A higher fat content indicates a higher cholesterol content too in poultry meat and vice versa.

TABLE III

EFFect of AdDing Garlic Flour (GF) on Cholesterol, HDL, LDL Blood, Nutrient, Cholesterol Content (\%) IN THE MEAT OF SRFC.

\begin{tabular}{lrrrrr}
\hline Observed Variables & R0 & R1 & R2 & R3 & R4 \\
\hline Blood Cholesterol (mg/dl) & $151.6^{\mathrm{a}} \pm 5.39$ & $143.7^{\mathrm{b}} \pm 0.47$ & $134.9^{\mathrm{c}} \pm 1.32$ & $131.6^{\mathrm{c}} \pm 4.33$ & $130.6^{\mathrm{c}} \pm 0.97$ \\
Blood HDL (mg/dl) & $47.04^{\mathrm{a}} \pm 0.90$ & $46.32^{\mathrm{b}} \pm 0.77$ & $45.76^{\mathrm{b}} \pm 0.71$ & $42.67^{\mathrm{c}} \pm 0.57$ & $41.96^{\mathrm{c}} \pm 0.31$ \\
Blood LDL (mg/dl) & $114.6^{\mathrm{c}} \pm 4.87$ & $107.5^{\mathrm{a}} \pm 0.47$ & $111.8^{\mathrm{b}} \pm 1.32$ & $111.6^{\mathrm{b}} \pm 4.33$ & $108.8^{\mathrm{a}_{ \pm}} \pm .96$ \\
Meat Cholesterol (mg/100g) & $68.63^{\mathrm{a}} \pm 4.37$ & $60.44^{\mathrm{b}} \pm 0.38$ & $57.08^{\mathrm{c}} \pm 2.73$ & $52.53^{\mathrm{c}} \pm 4.60$ & $40.39^{\mathrm{d}} \pm 5.77$ \\
Meat Water (\%) & $73.61^{\mathrm{a}}{ }_{ \pm 0}+0.54$ & $73.80^{\mathrm{a}} \pm 0.89$ & $73.40^{\mathrm{a}} \pm 0.44$ & $74.14^{\mathrm{b}} \pm 0.58$ & $73.82^{\mathrm{a}} \pm 0.56$ \\
Meat Protein (\%) & $20.39^{\mathrm{a}} \pm 0.46$ & $22.33^{\mathrm{b}} \pm 0.13$ & $23.02^{\mathrm{c}} \pm 0.20$ & $23.21^{\mathrm{c}} \pm 0.39$ & $23.24^{\mathrm{c}} \pm 0.75$ \\
Meat Fat (\%) & $2.20^{\mathrm{c}} \pm 0.05$ & $2.23^{\mathrm{c}} \pm 0.04$ & $2.12^{\mathrm{b}} \pm 0.05$ & $2.12^{\mathrm{b}} \pm 0.04$ & $2.08^{\mathrm{a}} \pm 0.04$ \\
\hline \multicolumn{4}{c}{ Note: *) Different Superscript in the same column showed Significant differently $(\mathrm{P}<0.01)$} &
\end{tabular}

\section{G. Blood Cholesterol, High-Density Lipoprotein (HDL) Blood Levels, Low-Density Lipoprotein (LDL) Blood Levels}

The average blood cholesterol of SFRC given GF $4 \%$ is $130.6 .7 \%-151.6 \% \mathrm{mg} / \mathrm{dl}$, average HDL is $42.67-47.04 \mathrm{mg} / \mathrm{dl}$, LDL level is $108.8-114.6 \mathrm{mg} / \mathrm{dl}$. The results of research on soy glycinin supplementation improved performance, blood biochemical index, and quality of broiler chicken, obtained blood cholesterol values of $72.33-104.11 \mathrm{mg} / \mathrm{dl}$, blood LDL 41.99 -55.99 (mg / dl), blood HDL 33-33.89 (mg / dl)[34].The result on the blood profile of broiler chickens produced blood cholesterol of 118.00-127.25 mg / dl, HDL 63.25 -72.42 mg / dl, LDL 27.30 - $34.70 \mathrm{mg} / \mathrm{dl}$ [32].
The result of the diversity analysis of blood cholesterol showed that the treatment of GF had a significantly different effect $(\mathrm{P}<0.01)$ (Table 3 ). Further test results showed that R0 blood cholesterol was significantly different $(\mathrm{P}<0.01)$ from $\mathrm{R} 1, \mathrm{R} 2, \mathrm{R} 3$, and R4. R1 was significantly different $(\mathrm{P}<0.01)$ from R1, R2, R3, and R4, but R2, R3, and R4 were not significantly different $(\mathrm{P}>0.01)$. This shows that a higher level of $4 \%$ of GF can reduce the blood cholesterol of SFRC.

Blood cholesterol decreases with the addition of GF. The level of low blood cholesterol is attributed to the active compound of garlic, which can reduce endogenous cholesterol synthesis in the liver, named allicin. Cholesterol biosynthesis containing unsulphine-oxide unsaturated (allicin) inhibits the enzyme heptic 3-hydro-3-methylglutaryl- 
CoA (HMG-CoA) reductase and cholesterol $7 \alpha$-hydroxilase enzyme in the process of cholesterol biosynthesis.

The diversity analysis result showed that $4 \%$ GF treatments were significantly different $(\mathrm{P}<0.01)$ to the HDL of SFRC blood. Tukey's HSD further test showed that R0 was significantly different from R1, R2, R3, and R4, but between $\mathrm{R} 1, \mathrm{R} 2$ and $\mathrm{R} 3, \mathrm{R} 4$ was not significantly different $(\mathrm{P}>0.05)$. Tukey's HSD further test showed that R0 was significantly different from R1, R2, R3, and R4, but between R1, R4 and $\mathrm{R} 2$, R3 was not significantly different $(\mathrm{P}>0.05)$. The occurrence of a significant difference caused by SNC feed factor with the addition of GF up to $4 \%$ and was reduce the body's cholesterol levels that changed the levels LDL of SNC.

Compounds containing sulfur such as allice in garlic may cause Blood lipids. Allicin is an active compound of unsaturated disulfide that has hypocholesterolemia with the following mechanism: Allyl propyl chains of allicin will easily be reduced to propyl chains, thereby reducing NADPH levels in the body, even though NDPH needed in cholesterol biosynthesis, cholesterol synthesis will be disrupted. Allicin also has binding properties on the functional part of the CoAenzyme in sulfhydryl clusters required for cholesterol biosynthesis.

\section{H. Meat Cholesterol}

The cholesterol level of SFRC meat that was fed with GF up to $4 \%$ was $52.53-68.63 \mathrm{mg} / 100 \mathrm{gr}$. The analysis of variance showed that the level of GF to the level of $4 \%$ had a significant effect $(\mathrm{P}>0.01)$ on meat cholesterol. Tukey's HSD test result showed that R4 was significantly different from R0, R1, R3, but $\mathrm{R} 1$ and $\mathrm{R} 2$ were not significantly different $(\mathrm{P}>0.05)$. The results show that increasing the level of $4 \%$ GF resulted in a decrease in blood cholesterol followed by a decrease in meat fat and SFRC meat cholesterol. GF contains aliin and alic essential oils related to antibacterial power, and a sulfurcontaining GF component called allicin can lower cholesterol. Allicin derived from garlic has antibacterial activity, both gram-negative and gram-positive. The activity of alliinase enzymes is to form thiosulfanate compounds. The role of alliinase enzymes against alliin (amino acids) containing sulfur atoms is to lower blood cholesterol levels and meat cholesterol levels. Garlic contains an allicin component that serves as antibacterial [35].

\section{Nutrient and Cholesterol Content (\%)}

Table 3 shows that GF to the level of $4 \%$ can reduce cholesterol levels in native chicken meat. This is because garlic contains alliin and allicin essential oils that have antibacterial activity, where the component sulfur-containing garlic called allicin can reduce meat cholesterol levels. Garlic can inhibit the production of cholesterol and fatty acids that are stimulants of heart disease and protect the body from cancer. Dialyl trisulfide can prevent infection and inflammation of the lining of the chicken bone marrow. In poultry, chronic aflatoxicosis indicated by stunted growth and changes in feed conversion [35]. Efforts to overcome and prevent aflatoxin contamination have been carried out using commercial and natural binding agents. Garlic contains an allicin component that functions as an antibacterial. Allicin derived from a fresh garlic extract has a broad antibacterial activity for both gram-negative and gram-positive bacteria.
Allicin is not formed in whole plants of garlic because whole garlic contains alliin and enzymalinase. If garlic is sliced or crushed, alliin will react with the enzyme linse to form allicin. Thiosulfanate compounds in garlic are formed due to the enzyme activity of alliin (an amino acid containing sulfur atoms), so the allicin can reduce cholesterol levels [28].

\section{J. Meat Water Content}

The average chicken meat water content that is surrounded by garlic is $73.61-74.14 \%$. The difference in water content in the animal's body is influenced by age variants and feeds. The result of the variance analysis showed that the administration of GF to $12 \%$ showed a significant effect $(\mathrm{P}<0.01)$ on meat moisture content. Further analysis of BNJ test showed water content in treatment R3 was significantly different $(\mathrm{P}<0.01)$ between R0, R1, R2, and R4, but not significantly different between R0, R1, R2, and R4 ( $P>0.05$ ). This shows that GF up to $4 \%$ can bind meat water derived from meat protein.

The ability to hold water is an important factor, especially in meat used in the food industry. Water holding capacity (WHC) of meat is the ability of meat protein to bind water in meat so that WHC can describe the level of damage to meat protein.

\section{K. Meat Protein Content}

The average protein of SFRC meat-fed GF up to $4 \%$ was $20.39-23.24 \%$. The variance analysis in meat protein levels showed that GF to $4 \%$ had a significant effect $(\mathrm{P}<0.01)$. Tukey's HSD test showed that R0 was significantly different $(\mathrm{P}<0.01$ ) from R1, R2, R3, and R4, whereas between R2, R3, and $\mathrm{R} 4$ was no significant difference $(\mathrm{P}>0.05)$. These results indicated that increasing the level of GF could provide increased SFRC meat protein. This is because of the high protein content of GF, where high protein consumption will affect the intake of protein in meat and sufficient amino acids in the body. The result of the effect of genotype on macronutrient antioxidants from broiler breast meat was $23.1 \%$. This shows that the meat protein given SFRC treatment is still in the normal range[36]. The increase in protein in SFRC meat with GF is attributed to higher protein positioned into the meat. Protein deposition is the amount of protein absorbed minus the protein utilized by the body where the availability of proteins and energy influences the level of protein deposition in the ratio [37]. GF contains an allicin compound that serves as a potent antibacterial to increase immunity. The more intensified protein, it can also contribute to protein deposition, resulting in high meat protein.

\section{Fat Meat Content}

Average values of SFRC meat fat treated with GF up to $4 \%$ were $2.08-2.23 \%$. The research results on the quality performance of chicken meat reared in the free-range program showed an average meat fat content of $2.67 \%$ [38]. The variance analysis result showed that GF to $4 \%$ in the diet given had a significant effect $(\mathrm{P}<0.01)$ on the fat content of meat. Further tests on meat fat showed that R4 was significantly different from R0, R1, R2, and R3. This showed that a higher level of GF to $4 \%$ reduces the fat of SFRC meat. GF has a metabolic effect in decreasing blood cholesterol and triglycerides. Decreased cholesterol levels of meat SFRC with the addition of GF at the level of $4 \%$ caused by the active 
compound garlic that can decrease the synthesis of endogenous cholesterol in the liver, namely allicin, unsaturated disulfide-oxide (allicin) inhibits the hepatic enzyme 3-hydroxy-3-methylglutaryl-CoA (HMG-CoA) reductase and cholesterol enzyme $7 \alpha$-hydroxylase in the process of cholesterol biosynthesis [39]. Diosgenin (steroidal saponin) is a beneficial compound that controls hypercholesterolemia by inhibiting cholesterol absorption and increasing cholesterol excretion in feces.

\section{CONCLUSION}

The study showed that 4\% garlic flour in SFRC feeds had a significant effect $(\mathrm{P}<0.01)$ on dressed weight, carcass percentage, breast weight, heart liver, meat water, meat protein, and decreased levels of abdominal fat, meat cholesterol, meat fat, blood cholesterol, HDL blood, and LDL blood. The study concluded that adding up to $4 \%$ garlic flour to SFRC feed significantly affects both performances and characteristics of chicken livestock.

\section{ACKNOWLEDGMENT}

This research was supported and funded by the Ministry of Research and Technology (Ristek-BRIN) of the Republic of Indonesia through the University Leading Applied Research with contract number 206/SP2H/LT/DPRM/2019, and was conducted at Sam Ratulangi University.

\section{REFERENCES}

[1] M. Basri, M. N. Hidayat, and R. Rusny, "Percentage of Carcass and Protein Content of Breast Meat of Native Chicken Given Apu-Apu Flour (Pistia stratiotes)," Chalaza J. Anim. Husb., vol. 5, no. 1, pp. 2228, 2020, doi: 10.31327/chalaza.v5i1.1255.

[2] J. R. Leke, J. S. Mandey, F. Ratulangi, and M. Najoan, "Effect of tomato (Solanum lycopersicum L.) protein on carcass and meat quality of kampong chicken," J. Indones. Trop. Anim. Agric., vol. 43, no. 1, 2018, doi: 10.14710/jitaa.43.1.35-42.

[3] N. I. Varianti, U. Atmomarsono, and L. D. Mahfudz, "Pengaruh Pemberian Pakan dengan Sumber Protein Berbeda terhadap Efisiensi Penggunaan Protein Ayam Lokal Persilangan," J. Agripet, vol. 17, no. 1, pp. 53-59, 2017, doi: 10.17969/agripet.v17i1.7257.

[4] C. Hidayat and S. Iskandar, "The influence of dietary protein and energy levels on the performance, meat bone ratio and meat chemical composition of SenSi-1 Agrinak chicken," J. Ilmu Ternak dan Vet., vol. 24, no. 1, pp. 1-8, 2019, doi: 10.14334/jitv.v24i1.1913.

[5] C. Manyi-Loh, S. Mamphweli, E. Meyer, and A. Okoh, Antibiotic use in agriculture and its consequential resistance in environmental sources: Potential public health implications, vol. 23, no. 4. 2018.

[6] U. Santoso, Y. Fenita, K. Kususiyah, K. Rusdi, E. M. Savitri, and N. W. Simanjutak, "Effect of Turmeric and Garlic Inclusion to Sauropus androgynus-Bay Leaves Containing Diets on Performance, and Carcass Quality of Broilers," Bul. Peternak., vol. 44, no. 4, pp. 233239, 2020, doi: 10.21059/buletinpeternak.v44i4.52285.

[7] S. Sugiharto, T. Yudiarti, I. Isroli, E. Widiastuti, and H. I. Wahyuni, "Hematological parameters and selected intestinal microbiota populations in the Indonesian indigenous crossbred chickens fed basal diet supplemented with multi-strain probiotic preparation in combination with vitamins and minerals," Vet. World, vol. 11, no. 6, pp. 874-882, 2018, doi: 10.14202/vetworld.2018.874-882.

[8] B. Divya, B. Suman, Ll. kumar, M. Venkataswamy, B. Eswari, and K. Thyagaraju, "The Role of Allium Sativum (Garlic) in Various Diseases and Its Health Benefits: a Comprehensive Review.," Int. J. Adv. Res., vol. 5, no. 8, pp. 592-602, 2017, doi: 10.21474/ijar01/5094.

[9] K. Damaziak, J. Riedel, D. Gozdowski, J. Niemiec, A. Siennicka, and D. Róg, "Productive performance and egg quality of laying hens fed diets supplemented with garlic and onion extracts," J. Appl. Poult. Res., vol. 26, no. 3, pp. 337-349, 2017, doi: 10.3382/japr/pfx001.

[10] I. N. S. Jaya, N. K. D. Haryani, and B. Indarsih, "The addition of fresh garlic (Allivum sativum L.) in duck feed reduces cholesterol content of duck egg," J. Kedokt. Hewan - Indones. J. Vet. Sci., vol. 12, no. 4, pp. 104-106, 2019, doi: 10.21157/j.ked.hewan.v12i4.9028.

[11] J. R. Leke, J. S. Mandey, and F. J. Nangoy, "Nutrients and cholesterol of eggs affected by dried tomato meal in laying hens diet," Int. J. Adv. Sci. Eng. Inf. Technol., vol. 5, no. 3, pp. 178-180, 2015, doi: 10.18517/ijaseit.5.3.522.

[12] P. Sunu, D. Sunarti, L. D. Mahfudz, and V. D. Yunianto, "Prebiotic activity of garlic (Allium sativum) extract on Lactobacillus acidophilus," Vet. World, vol. 12, no. 12, pp. 2046-2051, 2019, doi: 10.14202/vetworld.2019.2046-2051.

[13] E. A. Ibrahim, "In Vitro Antimicrobial Activity of Allium sativum (Garlic) Against Wound Infection Pathogens," J. Med. Sci., vol. 2, no. 8, pp. 1-8, 2017.

[14] T. Zhang, Y. Yang, Y. Liang, X. Jiao, and C. Zhao, "Beneficial effect of intestinal fermentation of natural polysaccharides," Nutrients, vol. 10, no. 8, 2018, doi: 10.3390/nu10081055.

[15] B. Borgohain, J. Mahanta, R. Islam, D. Sapcota, S. Sarma, and M. Borah, "Effect of Feeding Garlic (Allium sativum) as Prebiotic on the Performance of Broiler Chicken," Int. J. Livest. Res., vol. 7, no. 7, p. 1, 2017, doi: 10.5455/ijlr.20170520043023.

[16] M. Asrat, T. Zeryehun, N. Amha, and M. Urge, "Effects of supplementation of different levels of garlic (Allium sativum) on egg production, egg quality and hatchability of White Leghorn chicken," Livest. Res. Rural Dev. , vol. 30, no. 3, pp. 1-8, Mar. 2018, Accessed: Jul. 26, 2020. [Online]. Available: http://www.lrrd.org/lrrd30/3/tesf30037.html.

[17] J. R. Leke, E. Wantasen, F. Sompie, F. H. Elly, and R. Siahan, "The Characteristics and Quality of Egg from Commercial Laying Hens Fed with Garlic (Allium Sativum) Supplemented Ration," Anim. Prod., vol. 21, no. 2, p. 98, 2020, doi: 10.20884/1.jap.2019.21.2.746.

[18] B. Borgohain, J. D. Mahanta, D. Sapcota, B. Handique, and R. Islam, "Effect of Feeding Garlic (Allium sativum) on Haematological, Serum Biochemical Profile and Carcass Characteristics in Broiler Chicken," Int. J. Curr. Microbiol. Appl. Sci., vol. 8, no. 10, pp. 492-500, 2019, doi: 10.20546/ijcmas.2019.810.054.

[19] M. S. Ali, M. Kamruzzaman, and Z. H. Khandaker, "Effects of feeding garlic powder on growth performance and meat quality of broiler," Bangladesh J. Anim. Sci., vol. 45, no. 2 SE-Articles, Sep. 2016, doi: 10.3329/bjas.v45i2.29815.

[20] Soeparno, Ilmu Dan Teknologi Daging , 4th ed. Gadjah Mada University Press, 2005.

[21] D. Gudev, S. Popova-Ralcheva, I. Ianchev, and P. Moneva, "Effect of betaine and air ammonia concentration on broiler performance, plasma corticosterone level, lymphoid organ weights and some haematological indices," Biotechnol. Anim. HusbandryBiotehnologija u Stoc., vol. 27, no. 3, pp. 687-703, 2011, doi: 10.2298/bah1103687g.

[22] A. of O. A. Chemist, "Official Methods of Analysis of the Association of Official Analytical Chemists,” J. Assoc. Off. Agric. Chem., vol. 1, no. 15,1990 , doi: 10.7312 /seir17116-004.

[23] S. R.G.D and T. J.H, Principles and Procedures of Statistics. New York, Toronto, London, 1995

[24] C. Jacob, J. Leke, C. Sarajar, and L. Tangkau, "Penampilan Produksi Ayam Kampung Super Melalui Penambahan Juice Daun Gedi (Abelmochus Manihot L. Medik) Dalam Air Minum," J. Zootec Univ. Sam Ratulangi, vol. 39, no. 2, 2019, [Online]. Available: https://ejournal.unsrat.ac.id/index.php/zootek/article/download/25545 125197.

[25] I. Darmawan, E. Suprijatna, and U. Atmomarsono, "Effect of Frequency and Feeding Period on Carcass Production in Crossbred Native Chicken," J. Sains Peternak. Indones., vol. 19, no. 1, pp. 1015, 2017, doi: 10.31186/jspi.id.14.3.306-311.

[26] Y. Zhang, W. Jing, N. Zhang, J. Hao, and J. Xing, "Effect of maternal folate deficiency on growth performance, slaughter performance, and serum parameters of broiler offspring," J. Poult. Sci., vol. 57, no. 4, pp. 270-276, 2020, doi: 10.2141/jpsa.0190125.

[27] N. Nuraini, Z. Hidayat, and K. Yolanda, "Performa Bobot Badan Akhir, Bobot Karkas serta Persentase Karkas Ayam Merawang pada Keturunan dan Jenis Kelamin yang Berbeda," Sains Peternak., vol. 16, no. 2, p. 69, 2018, doi: 10.20961/sainspet.v16i2.23236.

[28] M. M. D. Utami, D. Pantaya, and A. Agus, "Addition of Garlic Extract in Ration to Reduce Cholesterol Level of Broiler," J. Phys. Conf. Ser., vol. 953, no. 1, 2018, doi: 10.1088/1742-6596/953/1/012124.

[29] R. . Murray, D. . Granner, and P. . Mayes, Biokimia Harper, 25th ed. Penerbit Buku Kedokteran, 2003.

[30] E. Tugiyanti and E. Susanti, "The Effect of Breadfruit Leaf Flour (Artocarpus altilis) on Number of Blood Cells And Correlation Between Cholesterol Blood and Meat of Tegal Ducks 10 Weeks Age," 
Anim. Prod., vol. 19, no. 3, p. 179, 2018, doi: 10.20884/1.jap.2017.19.3.635.

[31] H. Amagase, B. Petesch, H. Matsuura, S. Kasuga, and Y. Itakura, "Intake of Garlic and Its Bioactive Components," J. Nutr., vol. 131, no. 3, pp. 955S-962S, 2001

[32] O. V. Obajuluwa, K. A. Sanwo, L. T. Egbeyale, and A. O. Fafiolu, "Performance, blood profile and gut morphometry of broiler chickens fed diets supplemented with Yohimbe (Pausynistalia yohimbe) and Larvacide," Vet. Anim. Sci., vol. 10, no. April, p. 100127, 2020, doi: 10.1016/j.vas.2020.100127.

[33] R. . Lawrie and D. Ledward, Lawrie's Meat Science, 7th Edition. Woodhead Publishing, 2006.

[34] A. Osman et al., "Dietary supplementation of soybean glycinin can alter the growth, carcass traits, blood biochemical indices, and meat quality of broilers," Poult. Sci., vol. 99, no. 2, pp. 820-828, 2020, doi: 10.1016/j.psj.2019.12.026.

[35] M. Keusgen, "Health and alliums," Allium Crop Sci. Recent Adv., pp. 357-378, Jan. 2002, doi: 10.1079/9780851995106.0357.
[36] P. Lengkidworraphiphat, R. Wongpoomchai, S. Taya, and S. Jaturasitha, "Effect of genotypes on macronutrients and antioxidant capacity of chicken breast meat," Asian-Australasian J. Anim. Sci., vol. 33, no. 11, pp. 1817-1823, 2020, doi: 10.5713/ajas.19.0736.

[37] Berliana, Nelwida, and Nurhayati, "Massa Protein dan Lemak Daging Dada pada Ayam Broiler yang Mengkonsumsi Ransum Mengandung Bawang Hitam ( Black garlic ) Breast Meat Mass Protein and Fat of Broiler Chicken Consumed Diet Containing Black Garlic," J. Sains Peternak. Indones., vol. 18, no. 1, pp. 15-22, 2020.

[38] F. Mosca, L. Zaniboni, S. Stella, C. A. Kuster, N. Iaffaldano, and S. Cerolini, "Management and production research note: Slaughter performance and meat quality of Milanino chickens reared according to a specific free-range program," Poult. Sci., vol. 97, no. 4, pp. 1148 1154, 2018, doi: 10.3382/ps/pex439.

[39] S. Yalçin, I. Onbaşilar, A. Şehu, and S. Yalçin, "The effects of dietary garlic powder on the performance, egg traits and blood serum cholesterol of laying quails," Asian-Australasian J. Anim. Sci., vol. 20, no. 6, pp. 944-947, 2007, doi: 10.5713/ajas.2007.944. 